\title{
Pengetahuan Ibu HIV Mempengaruhi Perilaku Pencegahan Penularan HIV/AIDS dari Ibu ke Bayi di Provinsi Jawa Tengah
}

\author{
Khoiriyah Isni*), Zahroh Shaluhiyah $^{* *)}$, Kusyogo Cahyo ${ }^{* * *)}$ \\ *) Prodi IKM, Fakultas Kesehatan Masyarakat Universitas Ahmad Dahlan \\ Korespondensi: khoiriyah.isni@ gmail.com \\ ${ }^{*}$ Magister Promosi Kesehatan Universitas Diponegoro Semarang \\ ${ }^{* * *)}$ Fakultas Kesehatan Masyarakat Universitas Diponegoro
}

\section{ABSTRAK}

PMTCT merupakan program pemerintah untuk menekan terjadinya penularan HIV/AIDS ke bayi. Inti dari kegiatan PMTCT adalah strategi mencegah terjadinya penularan HIV/AIDS dari ibu ke bayi pada ibu hamil yang telah terinfeksi HIV. Namun masih terdapat ibu HIV yang terlambat mengetahui status HIV sehingga tidak ikut serta dalam PMTCT. Penelitian ini bertujuan mengetahui perilaku ibu HIV dalam upaya mencegah penularan HIVIAIDS dari ibu ke bayi. Penelitian ini merupakan penelitian kuantitatif dengan pendekatan cross sectional. Pengambilan data dilakukan pada 32 ibu HIV yang memiliki balita di Provinsi Jawa Tengah. Analisis data menggunakan analisis univariat dengan distribusi frekuensi, bivariat menggunakan Chi-Square dan Fisher Exact, dan multivariat menggunakan regresi logistik. Hasil penelitian menunjukkan bahwa faktor yang berhubungan dengan perilaku ibu HIV dalam pencegahan penularan HIV/AIDS dari ibu ke bayi adalah usia bayi, waktu diketahui status HIV, waktu mulai mengikuti ARV, keikutsertaan PMTCT, waktu mulai mengikuti PMTCT, dan pengetahuan. Sedangkan faktor yang paling dominan terhadap perilaku ibu HIV dalam pencegahan penularan HIV/AIDS dari ibu ke bayi adalah pengetahuan. Dari penelitian ini, maka dapat disimpulkan bahwa pengetahuan dapat mempengaruhi perilaku ibu HIV dalam pencegahan penularan HIV/AIDS dari ibu ke bayi.

Kata kunci : Ibu HIV, Pencegahan Penularan HIV/ADS dari ibu ke bayi, Provinsi Jawa Tengah

\begin{abstract}
Behavior of HIV-Positive Mothers in Prevention Mother to Child Transmission of HIV/AIDS in Central Java Province

PMTCT was government program to suppres HIV/AIDS and child. The point of PMTCT activities was a strategy to prevent HIV/AIDS transmission from mothers living with HIV/AIDS to their child. However, there were mothers living with HIV/AIDS who have been too late knowing their status HIV status so that they did not join PMTCT. This study aims to learn about HIV-positive mothers behavior in preventing of HIV/AIDS transmission from mother to child. This research was a quantitative with cross sectional approach. The data was collected from 32 mothers living with HIV/AIDS who had toddler babies in Central Java Province. Data were analyzed using univariate with frequency distribution, bivariate with chi square and fisher exact, and multivariate with logistic regression. The result showed that the variable which correlated towards behavior of HIV-positive mothers in preventing HIV/AIDS transmission from mother to child were age of child, HIV status reveal time, time of joining ARV, joining PMTCT, time of joining PMTCT, and knowledge. While, knowledge was the main variable that has considerable influence on the behavior of HIV-positive mothers. From this research, can be conclude that knowledge can affect HIV-positive mother's behavior.
\end{abstract}


Keywords: HIV-positive mothers, PMTCT, Central Java Province

PENDAHULUAN

Di Indonesia, infeksi HIV merupakan salah satu masalah kesehatan utama dan salah satu penyakit menular yang dapat mempengaruhi kematian ibu dan anak. Sedangkan Data hasil kegiatan dari Kemenkes RI tahun 2012 menunjukkan dari $43.264 \mathrm{ibu}$ hamil yang menjalani tes HIV, 1.329 (3,04\%) positif terinfeksi HIV (KPAN, 2013). Data lain hasil Pemodelan Matematika Epidemi HIV tahun 2012 juga menunjukkan bahwa prevalensi infeksi HIV pada ibu hamil diperkirakan akan meningkat dari 0,38 persen pada tahun 2012 menjadi 0,49 persen pada tahun 2016. Dari angka tersebut maka diperkirakan kebutuhan layanan Pencegahan Penularan HIV dari Ibu ke Anak (PPIA) juga akan meningkat dari 13.189 orang di tahun 2012 menjadi 16.191 orang pada tahun 2016. Selain itu jumlah anak berusia dibawah 15 tahun yang tertular HIV dari ibunya juga akan meningkat dari 4.361 orang di tahun 2012, menjadi 5.565 orang di tahun 2016. Hal ini tentu akan berakibat juga pada peningkatan angka kematian anak akibat AIDS. Sementara itu, jumlah kematian terkait AIDS pada populasi usia 15-49 tahun akan meningkat hampir dua kali lipat di tahun 2016 (Kemenkes, 2012).
Strategi yang paling tepat untuk mencegah penularan vertikal adalah melarang ibu yang terinfeksi HIV untuk hamil, dan melakukan terminasi kehamilan bagi ibu terinfeksi HIV. Akan tetapi hal ini tidak mungkin dilakukan karena setiap orang pasti menginginkan keturunan. Kehamilan serta memiliki keturunan adalah hak setiap manusia. Penderita HIV juga memiliki hak yang sama untuk menikah dan melanjutkan keturunan. Oleh karena itu, agar bayi tidak terinfeksi HIV maka dilakukan strategi pencegahan yaitu PMTCT (Damania, 2006). PMTCT merupakan program pencegahan penularan HIV/AIDS dari ibu ke bayi. Konsep dasarnya adalah menurunkan Viral Load serendah-rendahnya. Meminimalkan paparan janin/bayi dari cairan tubuh HIV positif. Lalu mengoptimalkan kesehatan bayi dari ibu dengan HIV positif.

Strategi dalam pencegahan penularan HIV dari ibu ke bayi, World Health Organization (WHO) mempromosikan pendekatan komprehensif, yang meliputi empat komponen (prong) berikut yaitu (1) Pencegahan primer infeksi HIV diantara perempuan usia subur, (2) Mencegah kehamilan yang tidak diinginkan antara perempuan yang hidup dengan HIV, (3) Mencegah penularan HIV dari seorang wanita 
yang hidup dengan HIV untuk bayinya, dan (4) Memberikan perawatan yang tepat, perawatan dan dukungan untuk ibu yang hidup dengan HIV dan anak-anak dan keluarga mereka (WHO, 2010). Walaupun berbagai upaya telah dilaksanakan selama beberapa tahun, ternyata cakupan PMTCT masih rendah, yaitu $10 \%$ di tahun 2004, kemudian meningkat menjadi 35\% pada tahun 2007 dan 45\% di tahun 2008 sesuai dengan laporan Universal Akses 2009. Bahkan pada laporan Universal Akses 2010, cakupan layanan PMTCT di Indonesia masih sangat rendah, yaitu sebesar 6\%, sehingga upaya peningkatan cakupan sejalan dengan program pencegahan perlu ditingkatkan.

Jawa Tengah menduduki urutan ke lima dengan kasus HIV/AIDS terbanyak dari bulan januari hingga juni 2013. Kasus HIV/AIDS di Jawa Tengah berdasarkan fakto risiko penularan didominasi oleh kaum heteroseksual $(81,7 \%)$ dan jumlah kasus terbanyak kedua adalah pada ibu rumah tangga. Jika dibiarkan dan tidak ada intervensi pada kaum perempuan termasuk ibu rumah tangga, maka kasus HIV pada ibu rumah tangga akan meningkat yang diiringi dengan peningkatan kasus HIV pada anak. Penularan melalui perinatal menyumbang $5,1 \%$ kasus HIV/AIDS di Jawa Tengah menurut faktor risiko penularan (KPA Jateng, 2013).
Berdasarkan data Kementerian Kesehatan Republik Indonesia, di Jawa Tengah mulai tahun 2010 sampai dengan bulan Juni 2013, jumlah kumulatif ibu hamil yang telah mendapatkan layanan PMTCT sebanyak 181 orang (Kemenkes, 2013). Dinas Kesehatan Provinsi Jawa Tengah melaporkan dari bulan januari hingga juni 2013 terdapat 43 ibu dengan HIV positif dengan rentang usia 20-49 tahun dengan 16 kelahiran secara seksio sesarea dan 6 kelahiran secara per vaginam. Serta terdapat 23 bayi lahir hidup dari ibu HIV positif dan 3 bayi yang diperiksa HIV dengan hasil positif, 46 bayi yang diberikan Makanan Pengganti ASI (MPASI) dan 40 bayi yang diberikan MPASI dan ASI secara bersamaan dari bulan januari hingga juni 2013. Pada bulan februari 2013, terdapat 6 bayi yang diberikan ASI.

Berbagai macam upaya komprehensif terkait pencegahan penularan dari ibu ke bayi telah dilakukan oleh fasilitas kesehatan. Namun tidak semua layanan kesehatan yang berada di kabupaten/kota dapat memberikan layanan HIV/AIDS termasuk layanan PMTCT. Sebagian besar layanan kesehatan yang berada di kabupaten/kota yang tidak mampu menangani pasien perempuan HIV sampai pada tindakan besar seperti persalinan ibu HIV segera dirujuk ke Rumah sakit rujukan terdekat. Hal inilah yang 
menyebabkan perempuan HIV terutama yang sedang hamil atau memiliki balita tidak optimal dalam mengakses layanan PMTCT. Terlebih tanpa adanya dukungan dari orang terdekat seperti pasangan atau suami dan keluarga. Berdasarkan laporan cakupan Dirjen Kesehatan Ibu Kementerian Kesehatan tahun 2012, cakupan ANC di Indonesia secara nasional mencapai lebih dari $90 \%$ untuk K-1 yang menunjukkan tingginya akses terhadap pelayanan pemeriksaan antenatal. Namun jika cakupan ANC dibandingkan dengan rendahnya cakupan pelayanan PPIA, termasuk pengobatan ARV, tampak kenyataan adanya miss-opportunity. Artinya ada Ibu hamil HIV yang tidak mengetahui statusnya, padahal sebenarnya dia sudah datang ke fasilitas layanan kesehatan untuk ANC (Kemenkes, 2013). Hal tersebut menunjukkan masih adanya ibu hamil yang tidak mengikuti PPIA yang mengakibatkan naiknya jumlah kasus HIV pada anak. Pelaksanaan antenatal care sendiri belum berjalan optimal, masih banyak fasilitas kesehatan yang belum menerapkan layanan antenatal care terpadu dengan layanan PMTCT.

Sejauh ini, pelaksanaan program pencegahan penularan HIV-AIDS dari ibu ke anak (PPIA) masih banyak kendala sejak dicanangkan pemerintah pada tahun 2004. Kendala yang dialami diantaranya di fasilitas kesehatan yang belum memadai, tidak semua fasilitas kesehatan mampu memberikan layanan PMTCT. Cakupan pelayanan antenatal K1 sudah cukup tinggi yaitu 92,7\% namun cakupan pelayanan antenatal K4 (kualitas) baru mencapai 61,4\% artinya masih banyak ibu hamil yang belum mendapat layanan yang berkualitas yaitu yang untuk mencegah dan mendeteksi dini terjadinya masalah/penyakit yang diderita ibu hamil maupun janinnya, termasuk HIV pada ibu hamil. Hal tersebut menjadikan kendala lainnya yaitu keterlambatan mengetahui status HIV ibu hamil yang akan berdampak pada perilaku ibu dalam mencegah penularan HIV/AIDS ke bayi.

\section{METODE}

Jenis penelitian ini adalah penelitian non eksperimental (observasional) dengan pendekatan cross sectional. Penelitian dilaksanakan tahun 2013-2014 pada ibu HIV yang memiliki balita. Jumlah ibu HIV yang memiliki balita di Provinsi Jawa Tengah adalah 32 orang, dan diambil dengan total sampling. Variabel independen dalam penelitian ini adalah umur bayi, waktu diketahuinya status HIV ibu, waktu mulai mengikuti ARV, keikutsertaan dalam PMTCT, waktu mulai mengikuti PMTCT, dan pengetahuan. Sedangkan variabel 
dependennya adalah perilaku ibu HIV dalam pencegahan penularan HIV/AIDS dari ibu ke bayi. Alat penelitian yang digunakan adalah kuesioner. Pengumpulan data dilakukan dengan metode wawancara. Hasil penelitian dianalisis secara univariat, bivariat, dan multivariat. Analisis bivariat menggunakan chi-square, dan analisis multivariat menggunakan regresi logistik.

\section{HASIL DAN PEMBAHASAN}

\section{Perilaku Ibu HIV dalam Pencegahan} Penularan HIV/AIDS dari Ibu ke Bayi

Berdasarkan hasil penelitian terkait perilaku ibu HIV dalam upaya pencegahan penularan HIV/AIDS dari ibu ke bayi, lebih dari sebagian responden sebanyak 56,3\% memiliki perilaku yang baik dalam pencegahan penularan HIV/AIDS dari ibu ke bayi, sedangkan sisanya sebanyak 43,8\% memiliki perilaku pencegahan penularan HIV/AIDS dari ibu ke bayi yang buruk. Inti dari kegiatan pencegahan penularan HIV/AIDS dari ibu ke bayi adalah strategi dalam mencegah terjadinya penularan HIV/AIDS dari ibu ke bayi pada ibu hamil yang telah terinfeksi HIV. Jadi inti kegiatan PMTCT terletak pada prong 3. Prong 3 meliputi layanan ANC terpadu termasuk penawaran dan tes HIV, diagnosis HIV, pemberian terapi ARV, persalinan aman, tatalaksana pemberian makanan bagi bayi, mengatur kehamilan dan keluarga berencana, pemberian profilaksis ARV dan kotrimoksazol pada anak, dan pemeriksaan diagnostik HIV pada bayi yang lahir dari ibu dengan HIV (Kemenkes, 2012). Kegiatan prong 1 tidak termasuk dalam penelitian ini karena responden yang diteliti adalah ibu dengan HIV positif dan telah memiliki anak, sehingga pencegahan penularan HIV pada perempuan usia reproduksi (15-49 tahun) atau prong 1 tidak terlaksana.

Jumlah responden yang melahirkan dengan cara pervaginam sebanyak $65,6 \%$ dan jumlah responden yang melahirkan dengan cara seksio sesarea sebanyak 34,4\%. Jumlah responden yang melakukan konsultasi terlebih dahulu sebelum memutuskan untuk memilih cara persalinan sebanyak 53,1\%, sisanya sebanyak 46,9\% tidak melakukan konseling sehubungan dengan memutuskan cara persalinan. Alasan responden tidak melakukan konseling terlebih dahulu sebelum memutuskan cara persalinan adalah belum mengetahui status HIV saat persalinan, mereka baru mengetahui status HIV setelah melakukan persalinan. Persalinan dengan cara pervaginam atau normal aman atau boleh dilakukan ketika kondisi ibu hamil yang terinfeksi HIV memenuhi persyaratan yang telah ditetapkan yaitu viral load $<1.000$ 
kopi $/ \mu \mathrm{L}$ dan telah memulai terapi ARV pada usia kehamilan $\leq 14$ minggu. Ketika kondisi ibu hamil yang terinfeksi HIV tidak memenuhi persyaratan tersebut maka dianjurkan untuk melakkuan persalinan secara seksio sesarea. Hal tersebut dilakukan karena walaupun persalinan secara normal diperbolehkan untuk ibu hamil yang terinfeksi HIV, namun kemungkinan terjadinya penularan HIV ke bayi masih besar yaitu sekitar 10-20\% .

Penelitian kohort yang dilakukan di Inggris dan Negara Eropa lainnya menunjukkan bahwa penularan HIV/AIDS dari ibu ke bayi rata-rata $<0,5 \%$ pada perempuan dengan plasma viral load $<50$ kopi $/ \mu \mathrm{L}$, termasuk dalam HAART, dan tidak memperhatikan sehubungan dengan cara persalinan. Penelitian tersebut juga mendukung dan merekomendasikan praktik persalinan secara pervaginam apabila ibu hamil dengan HIV memenuhi persyaratan tersebut (British HIV Association, 2012). Dalam Tatalaksana Infeksi HIV dalam Kehamilan oleh Clara Marcaelia, dkk dijelaskan bahwa cara persalinan harus ditentukan sebelum umur kehamilan 38 minggu untuk meminimalkan terjadinya komplikasi persalinan, dan apabila diputuskan memilih persalinan secara seksio sesarea maka sebaiknya dijadwalkan pada umur kehamilan 39+ minggu, untuk meminimalkan risiko transient tachypea of the newborn (TTN) (Clara, 2010).

Hasil penelitian, jumlah responden yang melakukan tes HIV sebelum persalinan hanya sebanyak $34,4 \%$, sisanya sebanyak $65,6 \%$ responden tidak melakukan tes HIV sebelum persalinan. Sedangkan jumlah responden yang melakukan tes CD4 sebelum persalinan dan setelah persalinan adalah sebanding yaitu sebesar 50\%. Sebanyak 84,4\% responden tidak melakukan tes viral load sebelum persalinan dan hanya sebanyak 15,6\% responden yang melakukan tes viral load sebelum persalinan. Sedikitnya responden yang melakukan tes viral load dikarenakan harga tes yang sangat mahal sehingga responden merasa keberatan untuk melakukan tes tersebut. Tes CD4 dan tes viral load diperlukan untuk ibu hamil yang terinfeksi HIV sebelum melakukan persalinan karena untuk mengetahui kesehatan dan jumlah virus yang ada dalam darah ibu HIV sehingga dapat digunakan untuk pertimbangan saat memutuskan pemilihan cara persalinan.

Cara paling efektif untuk menekan replikasi HIV adalah dengan memulai pengobatan dengan kombinasi ARV yang efektif. Pemberian ARV pada ibu hamil dengan HIV selain dapat mengurangi risiko penularan HIV dari ibu ke anak adalah untuk mengoptimalkan kondisi kesehatan ibu dengan 
cara menurunkan kadar HIV serendah mungkin. ARV diberikan sedini mungkin ketika ibu hamil menunjukkan indikasi HIV. Hasil penelitian ini menunjukkan bahwa semakin mendekati fase menjelang kelahiran sampai dengan setelah kelahiran jumlah responden yang mengonsumsi ARV semakin banyak namun tetap masih terdapat responden yang tidak mengonsumsi ARV bahkan sampai setelah kelahiran yaitu sebesar $21,9 \%$. Selama kehamilan lebih dari sebagian responden (56,3\%) tidak mengonsumsi ARV dan pada saat menjelang kelahiran responden yang mengonsumsi dan tidak mengonsumsi ARV adalah sebanding yaitu 50\%. Hal ini dipengaruhi oleh berbagai faktor diantaranya adalah waktu diketahuinya status HIV responden yang berbeda-beda.

Pemberian ARV tidak hanya pada ibu saja, setelah persalinan bayi lahir dari ibu HIV wajib diberikan profilaksis ARV selama 6 minggu dan dilanjutkan kotrimoksazol untuk anak sampai dengan umur 1 tahun atau sampai diagnosis HIV ditegakkan. Dalam penelitian ini sebanyak $40,6 \%$ bayi responden masih diberikan profilaksis ARV bayi. Usia rata-rata bayi diberikan profilaksis untuk pertama kali adalah usia 5,72 minggu, dengan usia bayi terendah 0 minggu, dan usia bayi tertinggi pemberian profilaksis 80 minggu atau 20 bulan.
Menurut hasil penelitian, masih terdapat sebanyak 9,4\% responden yang memberikan ASI kepada bayinya, $87,5 \%$ reponden hanya memberikan susu formula saja, dan terdapat sebanyak 3,1\% responden yang memberikan ASI dan susu formula bersamaan. Responden yang pernah memberikan ASI dan susu formula sebanyak $37,5 \%$ dan rata-rata memberikannya lebih dari 2 kali.

Demikian, konseling terkait pemberian makanan bayi sangat diperlukan untuk menghindari hal-hal tersebut terjadi. Dalam konseling perlu diingatkan bahwa pemberian pengganti ASI jangan sampai berdampak lebih buruk, artinya pemberian susu formula boleh diberikan namun harus memenuhi syarat AFASS (Acceptable, Feasible, Affordable, sustainable, safe). Apabila tidak memenuhi syarat tersebut maka menurut WHO sebaiknya bayi diberikan ASI eksklusif tanpa makanan tambahan apapun selama 6 bulan. Sehubungan dengan hal tersebut, hampir sebagian resonden $(43,8 \%)$ tidak melakukan konseling pemberian makanan bayi dari ibu HIV (BIHA).

Pada bayi lahir dari Ibu HIV (BIHA) pemberian imunisasi juga perlu diperhatikan. Pedoman yang dianjurkan berbeda-beda dari tahun ke tahun. Dulu bayi lahir dari ibu HIV tidak boleh diberikan imunisasi yang berupa virus hidup seperti BCG, polio, dan campak. 
Pedoman WHO mengenai PMTCT menganjurkan semua imunisasi boleh dilakukan asalkan bayi tidak menunjukkan gejala klinis yang mengarah ke HIV. Namun tampaknya responden tidak mengetahui dengan benar terkait imunisasi yang tidak boleh diberikan apabila kondisi bayi dari ibu HIV tidak memungkinkan untuk diberikan imunisasi. Sehingga sebagian besar bayi responden telah diberikan semua imunisasi mulai dari BCG sampai dengan imunisasi campak.

Hasil penelitian lain menunjukkan bahwa pemberian imunisasi BCG saat kelahiran pada bayi yang terinfeksi HIV dan pada bayi yang menunjukkan gejala klinis AIDS, lebih meningkatkan risiko terkena penyakit TB di kemudian hari (Calles, 2010). Penelitian ini mengungkapkan bahwa masih terdapat ibu HIV yang memiliki perilaku buruk dalam pencegahan penularan HIV/AIDS yang dibuktikan oleh praktik responden terhadap aturan PMTCT yang tidak dipatuhi dan dilaksanakan oleh responden. Kondisi yang demikian tentunya dipengaruhi oleh beberapa faktor antara lain usia bayi, waktu diketahui status HIV responden, waktu mulai mengikuti terapi ARV, keikutsertaan PMTCT, waktu mulai mengikuti PMTCT, pengetahuan tentang pencegahan penularan HIV/AIDS dari ibu ke bayi.
Berdasarkan hasil penelitian ini dapat diketahui beberapa faktor yang berhubungan secara signifikan secara statistik terhadap perilaku ibu HIV dalam pencegahan penularan HIV/AIDS dari ibu ke bayi adalah usia bayi, waktu diketahui status HIV ibu, waktu mulai mengikuti ARV, keikutsertaan PMTCT, waktu mulai mengikuti PMTCT, dan pengetahuan tentang pencegahan penularan HIV/AIDS dari ibu ke bayi.

Hubungan yang terjadi diantara faktorfaktor tersebut dengan perilaku ibu HIV dalam pencegahan penularan HIV/AIDS dari ibu ke bayi menunjukkan adanya beberapa kecenderungan yaitu ibu HIV yang memiliki bayi usia diatas 18 bulan cenderung memiliki perilaku yang buruk dibandingkan dengan ibu HIV yang memiliki bayi usia dibawah 18 bulan. Demikian pula pada ibu HIV yang mengetahui status HIV ketika setelah kehamilan lebih cenderung berperilaku buruk daripada ibu HIV yang mengetahui status HIV sebelum kehamilan. Ibu HIV yang mulai mengikuti terapi ARV setelah kehamilan cenderung memiliki perilaku buruk dibandingkan dengan ibu HIV yang mulai mengikuti terapi ARV sebelum kehamilan. Sedangkan, ibu HIV yang tidak mengikuti PMTCT cenderung berperilaku buruk daripada ibu HIV yang mengikuti PMTCT. Begitu pula dengan ibu HIV yang berperilaku 
buruk lebih cenderung pada ibu HIV yang mulai mengikuti PMTCT setelah kehamilan dibandingkan dengan ibu HIV yang mulai mengikuti PMTCT sebelum kehamilan.

Berdasarkan nilai odds ratio yang diperoleh dari hasil multivariat menunjukkan bahwa variabel pengetahuan tentang pencegahan penularan HIV/AIDS dari ibu ke bayi memiliki pengaruh paling besar terhadap perilaku ibu HIV dalam pencegahan penularan HIV/AIDS dari ibu ke bayi di Provinsi Jawa Tengah. Ibu HIV yang memiliki pengetahuan yang tinggi tentang pencegahan penularan HIV/AIDS dari ibu ke bayi memiliki kecenderungan 9,259 kali lebih besar untuk berperilaku baik dalam pencegahan penularan HIV/AIDS dari ibu ke bayi dibandingkan dengan ibu HIV yang memiliki pengetahuan yang rendah.

\section{Karakteristik Ibu HIV Berdasarkan Usia Bayi}

Dari hasil penelitian menunjukkan bahwa sebagian besar bayi responden adalah berusia diatas 18 bulan $(56,3 \%)$, rata-rata usia bayi responden adalah 21,91 bulan, dengan usia terendah adalah 2 bulan, dan usia bayi yang paling tinggi adalah 48 tahun (4 tahun). Demikian menurut hasil analisis bivariat chisquare, diperoleh nilai $\mathrm{p}=0,025$ yang artinya terdapat hubungan yang signifikan antara usia bayi responden dengan perilaku pencegahan penularan HIV/AIDS dari ibu ke bayi.

Sesuai dengan pedoman PMTCT bahwa penularan HIV dari ibu ke anak pada umumnya terjadi pada saat persalinan dan saat menyusui. Persalinan memiliki risiko sebesar 10-20\%, sedangkan menyusui ASI berisiko lebih besar yaitu 5-20\%. Usia kurang dari 18 bulan merupakan usia yang masih rentan tertular HIV/AIDS dari ibu yang terinfeksi dan antibodi ibu masih terdeteksi pada bayi, sehingga tes HIV pada bayi dapat dilakukan setelah usia 18 bulan. Oleh karena itu, sebelum penegakan status HIV bayi, upaya pencegahan penularan HIV/AIDS dilakukan sedini mungkin setelah status HIV ibu diketahui. Upaya pencegahan penularan HIV ke bayi yang dapat dilakukan ibu HIV setelah persalinan diantaranya pemberian profilaksis bayi, pemberian nutrisi/makanan utama bayi, dan pemberian imunisasi (Kemenkes, 2012).

Dalam penelitian ini, setelah responden mengetahui status HIV,responden dianjurkan untuk mengikuti program PMTCT. Upaya yang dilakukan untuk mencegah penularan ke bayi mengikuti tahap dimana responden terdeteksi HIV. Responden yang terdeteksi HIV, setelah persalinan maka upaya yang dianjurkan untuk dilakukan yaitu memberikan susu formula kepada bayi, dan boleh 
memberikan imunisasi bayi apabila bayi tidak menunjukkan gejala klinis HIV atau AIDS. Namun untuk bayi dengan ibu terdeteksi HIV saat bayi usia setelah 18 bulan, maka dianjurkan untuk melakukan tes HIV terlebih dahulu pada bayi, sehingga penegakan status HIV jelas.

Umumnya pada bayi dengan ibu yang diketahui status HIV setelah bayi berusia 18 bulan, status HIV bayi juga positif. Selanjutnya, bayi diberikan terapi ARV bukan profilaksis bayi. Dalam penelitian ini, terdapat beberapa bayi dengan keadaan tersebut, namun terdapat juga responden yang melakukan upaya pecegahan penularan HIV/AIDS ke bayi saat sebelum kehamilan, menjelang persalinan, dan setelah persalianan. Risiko penularan HIV/AIDS dari ibu ke bayi dapat berkurang apabila upaya pencegahan dilakukan sedini mungkin.

\section{Karakteristik Ibu HIV Berdasarkan Waktu diketahui Status HIV}

Lebih dari sebagian responden sebesar 68,8\% mengetahui status HIV ketika setelah kehamilan, sisanya sebesar 31,3\% responden mengetahui status HIV sebelum kehamilan. Hasil analisis bivariat menggunakan uji fisher exact menunjukkan bahwa terdapat hubungan signifikan antara waktu diketahui status HIV dengan perilaku pencegahan penularan
HIV/AIDS dari ibu ke bayi, karena nilai $\mathrm{p}$ lebih kecil dari 0,05.

Selain kesiapan yang matang dalam merencanakan keturunan, mereka juga aktif mencari informasi terkait kesehatan bayi seperti pemberian makanan bayi dari ibu HIV, imunisasi bayi dari ibu HIV. Berbeda dengan responden yang mengetahui status HIV ketika setelah kehamilan atau dalam fase sedang hamil, saat menjelang kelahiran atau setelah melahirkan. Pada responden yang seperti ini, belum dapat menerima status HIVnya juga merasakan malas dan capek untuk mengakses layanan kesehatan. Kondisi kehamilan membuat mereka enggan mengikuti pengobatan. Perilaku yang demikian dapat berpengaruh terhadap kesehatan bayinya, apabila kesiapan mental dan pencegahan penularan dilakukan sedini mungkin, maka risiko penularan HIV/AIDS ke bayi dapat ditekan.

\section{Karakteristik Ibu HIV Berdasarkan Waktu Mulai Mengikuti terapi ARV}

Dari hasil analisis univariat menunjukkan bahwa, sebesar $75 \%$ responden kali pertama mengikuti terapi ARV ketika setelah kehamilan. Hanya sebesar 25\% responden yang mengikuti terapi ARV sebelum kehamilan. Hal ini dikarenakan responden baru mengetahui status HIV setelah kehamilan ketika kunjungan kehamilan (Antenatal care), 
ketika menjelang kelahiran, atau setelah kelahiran.

Berdasarkan hasil tabulasi silang, diketahui bahwa ibu HIV yang mempunyai perilaku buruk terhadap pencegahan penularan HIV/AIDS dari ibu ke bayi lebih banyak pada ibu HIV yang mengikuti terapi ARV ketika setelah kehamilan (58,3\%) dibandingkan dengan yang mengikuti terapi ARV sebelum kehamilan. Hal ini menunjukkan bahwa semakin cepat seseorang mengikuti terapi ARV maka semakin baik pula perilaku seseorang dalam melakukan upaya pencegahan termasuk pencegahan penularan HIV/AIDS dari ibu ke bayi. Hasil analisis bivariat menggunakan uji fisher exact, diperoleh nilai $\mathrm{p}=0,004$ dan dinyatakan bahwa terdapat hubungan antara waktu mulai mengikuti terapi ARV dengan perilaku ibu dalam pencegahan penularan HIV/AIDS dari ibu ke bayi.

Sejalan dengan penelitian ini, responden yang mengikuti terapi ARV pertama kali sejak sebelum kehamilan mengaku lebih peduli terhadap adanya kemungkinan penularan HIV ke bayi, sehingga pencarian informasi serta praktik terkait mencegah penularan HIV ke bayi lebih baik dilakukan daripada responden yang mengikuti terapi ARV setelah kehamilan.

\section{Karakteristik Ibu HIV Berdasarkan Keikutsertaan PMTCT}

Hasil analisis univariat menunjukkan bahwa sebesar 71,9\% responden tidak mengikuti PMTCT, sisanya sebesar 28,1\% mengikuti PMTCT. Berdasarkan hasil tabulasi silang, diketahui bahwa responden dengan perilaku buruk terhadap pencegahan penularan HIV/AIDS dari ibu ke bayi lebih banyak terdapat pada responden yang tidak mengikuti PMTCT $(60,9 \%)$ daripada yang mengikuti PMTCT.

Hasil analisis biavariat dengan menggunakan uji fisher exact sehingga diperoleh hasil nilai $\mathrm{p}=0,002$, dan dinyatakan terdapat hubungan yang signifikan antara keikutsertaan PMTCT dengan perilaku ibu dalam pencegahan penularan HIV/AIDS dari ibu ke bayi. Hal ini didukung oleh pernyataan responden terkait keikutsertaan PMTCT bahwa sebelum memutuskan untuk mengikuti program tersebut, responden telah mengetahui syarat-syarat dan informasi terkait PMTCT, sehingga responden mengerti benar apa yang dilakukan agar bayinya sehat dan penularan HIV dari ibu ke bayi tidak terjadi.

\section{Karakteristik Ibu HIV Berdasarkan Waktu} Mulai Mengikuti PMTCT

Mayoritas responden waktu kali pertama mengikuti PMTCT adalah ketika setelah 
kehamilan $(71,9 \%)$, sedangkan sisanya $28,1 \%$ waktu kali peratama mengikuti PMTCT ketika sebelum melahirkan. Hal ini dapat dikatakan bahwa sebagian besar responden tidak mengikuti PMTCT dari awal. Responden mulai mengikuti PMTCT saat sedang hamil, ketika menjelang kelahiran, atau setelah kelahiran.

Distribusi frekuensi menurut waktu mulai mengikuti PMTCT, sebesar 53,1\% responden tidak mengikuti PMTCT. Sedangkan yang mengikuti mengikuti PMTCT sejak sebelum kehamilan sebesar 28,1\%. Lainnya, sebesar 9,4\% responden mengikuti PMTCT ketika hamil dan menjelang persalinan. Hal ini menunjukkan bahwa masih banyak responden yang terlambat atau bahkan tidak mengikuti PMTCT mulai dari awal kehamilan.

Berdasarkan hasil tabulasi silang responden menurut waktu mulai mengikuti PMTCT, diketahui bahwa 60,9\% responden yang berperilaku buruk dalam mencegah penularan HIV/AIDS dari ibu ke bayi dengan waktu mulai mengikuti PMTCT ketika setelah kehamilan.

Hasil analisis bivariat dengan menggunakan uji fisher exact menunjukkan bahwa terdapat hubungan yang signifikan antara waktu mulai mengikuti PMTCT dengan perilaku pencegahan penularan HIV/AIDS dari ibu ke bayi, dengan nilai $\mathrm{p}=0,002$. Responden mengungkapkan bahwa dirinya terdeteksi HIV ketika hamil 5 bulan dan mempunyai infeksi oportunistik berupa TB, hal ini berpengaruh terhadap praktik dirinya dalam menjaga kesehatan bayinya seperti ketidakpatuhan minum obat ARV, pemberian ASI dan pemberian profilaksis bayi yang tidak rutin.

\section{SIMPULAN}

Ibu HIV yang memiliki perilaku buruk dalam pencegahan penularan HIV/AIDS dari ibu ke bayi yaitu sebesar $43,8 \%$. Pengetahuan merupakan faktor yang paling berpengaruh terhadap perilaku ibu HIV dalam pencegahan penularan HIV/AIDS dari ibu ke bayi. Faktorfaktor lain yang berhubungan dengan perilaku ibu HIV dalam pencegahan penularan HIV/AIDS dari ibu ke bayi yaitu usia bayi, waktu diketahui status HIV, waktu mulai mengikuti terapi ARV, keikutsertaan PMTCT, waktu mulai mengikuti PMTCT, pengetahuan tentang pencegahan penularan HIV/AIDS dari ibu ke bayi.

\section{ACKNOWLEDGEMENT}

Dalam hal ini penulis mengucapkan terima kasih kepada Menteri Pendidikan Nasional yang telah memberikan dukungan pembiayaan melalui Program Beasiswa Unggulan jalur Fast Track berdasarkan DIPA 
Sekretariat Jenderal Departemen Pendidikan Nasional Tahun Anggaran 2012 sampai dengan Tahun 2014.

\section{KEPUSTAKAAN}

British HIV Association. Guidelines For The Management of HIV Infection In Pregnant Women 2012. HIV Medicine. 2012.

Calles, NR; Schutze, GE. Immunizations for Children with HIV/AIDS. 2007.

Clara, MV; Kemara, KP; Megadhana, IW. Tatalaksana Infeksi HIV Dalam Kehamilan: Bagian/SMF Obstetri dan Ginekologi Fakultas Kedokteran Universitas Udayana/Rumah Sakit Umum Pusat Sanglah Denpasar.

Damania, KR. Prevention of mother to child transmission of HIV infection. The Journal of Obstetrics and Gynecology of India. 2006;56(5):390:5.

Kementerian Kesehatan Republik Indonesia. Laporan Hasil Pemodelan Matematika Epidemi HIV (Draft). Kementerian Kesehatan Republik Indonesia. Jakarta. 2012.

Kementerian Kesehatan Republik Indonesia. Rencana Aksi Nasional Pencegahan Penularan HIV dari Ibu ke Anak (PPIA) Indonesia 2013-2017. Menuju Akses
Universal. Kementerian Kesehatan Republik Indonesia. Jakarta. 2013.

Komisi Penanggulangan AIDS Provinsi Jawa Tengah. Kondisi HIV \& AIDS di Jawa Tengah 1993 s/d 31 Juni 2013. 2013.

Komisi Penanggulangan AIDS Nasional. Penularan HIV AIDS dari Ibu ke Anak Bisa Meningkat, Ini Langkah Kemenkes. Komisi Penanggulangan AIDS Nasional. Jakarta. 2013.

World Health Organization (WHO). PMTCT strategic vision 2010-2015: preventing mother-to-child transmission of HIV to reach the UNGASS and Millennium Development Goals. Geneva. 2010 